\title{
MODES AND FREQUENCIES OF COLONIZATION AND ITS RELATION TO EXTINCTIONS, HABITAT AND \\ SEASONALITY IN THE SOCIAL SPIDER ANELOSIMUS EXIMIUS IN THE AMAZON (ARANEIDAE: THERIDIIDAE)
}

\author{
By Eduardo M. Venticinque ${ }^{1}$, Harold G. Fowler ${ }^{2}$ \\ AND CARLOS A. SiLVA \\ Departamento de Ecologia \\ Instituto de Biociências \\ Universidade Estadual Paulista (UNESP) \\ 13506-900 Rio Claro, SP, Brazil
}

\section{INTRODUCTION}

The theridiid genus Anelosimus consists of 26 described species in the Americas. 14 of these are endemic to Chile and the Argentine Patagonia, while the remaining species are widely distributed through Central and South America (Levi, 1956, 1963, 1972). Of these, 4 species are known to have highly organized social behavior, and the best known, A. eximius Keyserling ranges from Argentina to Panama (Stejskal, 1976; Vollrath, 1982; Christenson, 1984).

Colony populations in $A$. eximius range from $<100$ to $>10000$ (Simon, 1891; Brach, 1975; Stejskal, 1976; Vollrath, 1982; Nentwig, 1985; Smith, 1989). Colonies of social species of Anelosimus characteristically have adult sex ratios highly skewed in favor of females (Fowler \& Levi, 1979; Vollrath, 1986a, 1986b; Aviles, 1986). Two forms of colony foundation have been recorded in social Anelosimus: dispersion of solitary gravid females, and group migration, or sociotomy (Fowler \& Levi, 1979; Vollrath, 1982; Christenson, 1984). Predation is intense on solitary dispersing gravid females (Vollrath, 1982; Christenson, 1984), and this should favor sociotomy (Vollrath, 1982).

However, all studies of colony foundation were performed with colonies in perturbed habitats and little is known of their behavior

\footnotetext{
${ }^{1}$ Present Address: Departamento de Zoologia, Instituto de Biociências, Universidade Estadual Paulista, 14600 Botucatu, SP, Brazil

2 for all correspondence

Manuscript received 24 August 1992
} 
and ecology in the forest interior. Pasquet \& Krafft (1989) concluded that it was highly improbable to find colonies in the forest interior, although Smith (1986) recorded colony clusters along a trail through continuous forest in Suriname. Moreover, the relation between colony extinctions and the intensity and types of colonization has not been examined.

In this paper, we examine populations of A. eximius in both continuous Amazonian forest as well as forest edges. Specifically, we document modes of colonizations, and their relation to habitat, seasonality and colony extinction rates.

\section{MATERIALS AND MethodS}

Studies were conducted in the Biological Dynamics of Forest Fragments Reserves of the Smithsonian Institution/World Wildlife Fund/National Institute for Amazonian Research (Manaus, Amazonia, Brazil) in both continuous forest (Cabo Frio Reserve) and forest edge (the road to Cidade de Powell) $\left(2^{\circ} 24^{\prime} \mathrm{S}, 59^{\circ} 52^{\prime} \mathrm{W}\right)$. Forests are typical "terra firme" forests (Pires and Prance, 1985), with canopy heights ranging from 30 to $37 \mathrm{~m}$, and emergent vegetation reaching 40 to $50 \mathrm{~m}$. 235 woody species have been recorded for 1 ha of this forest type (Pires \& Prance, 1985). Understory vegetation is characterized by the abundance of dwarf palms (Arecaceae) (Kahn \& Castro, 1985). Mean annual precipitation, averaged over a $30-\mathrm{yr}$ period, for nearby Manaus $(80 \mathrm{~km})$ is 2186 $\mathrm{mm}$.

Every 30 days from August, 1988, to August, 1989, fixed transects were walked in both study areas. All colonies encountered were individually numbered and marked with red or yellow banding tape. In this paper, we include only data on colony foundations and extinctions of colonies known to have been founded during our studies. Foundation types were divided into two types: solitary females, with or without egg sacs present, and sociotomy, in which groups consisted of a variable number of spiders of both sexes, often with juveniles.

\section{RESULTS}

144 incipient colonies were registered during the 12 months. Of these the forest border had 101, while the closed forest had only 
43. Nevertheless, mean incipient colony life-span for colonies in closed forest $\left(\overline{\mathrm{X}}=167\right.$ days, $\left.\mathrm{s}^{2}=111.4\right)$ was significantly higher than that recorded for incipient colonies in the forest border $\left(\overline{\mathrm{X}}=88\right.$ days, $\left.\mathrm{s}^{2}=68.9\right)(\mathrm{t}-5.20, \mathrm{P}<0.01)$.

Of the 101 colony foundations registered at the forest border, 20 were by solitary females, contrasted with only one of the 43 colony foundations witnessed for the closed forest $(\mathrm{G}=4.808$; $\mathrm{P}<0.05)$. Corresponding mean recorded life-spans were $119.3\left(\mathrm{~s}^{2}=94.22\right)$ days for colonies founded by sociotomy, and $66.6\left(\mathrm{~s}^{2}=52.12\right)$ days for foundations by solitary females $(\mathrm{t}=13.01 ; \mathrm{P}<0.01)$. Mean life span for colonies founded by sociotomy varied significantly between forest edge and interior ( $\overline{\mathrm{X}} 90$ vs 173 , respectively, $\mathrm{F}=22.26, \mathrm{P}<0.01$ ). As only one colony was founded by solitary females in the forest interior, it was impossible to compare life spans between settings.

The annual ratio of foundations to extinctions was 1.32 for the forest edge, and 1.86 for the forest interior. No significant differences were found between months in colony extinctions (Fig. 1; Table 1). However, significant differences in extinctions were

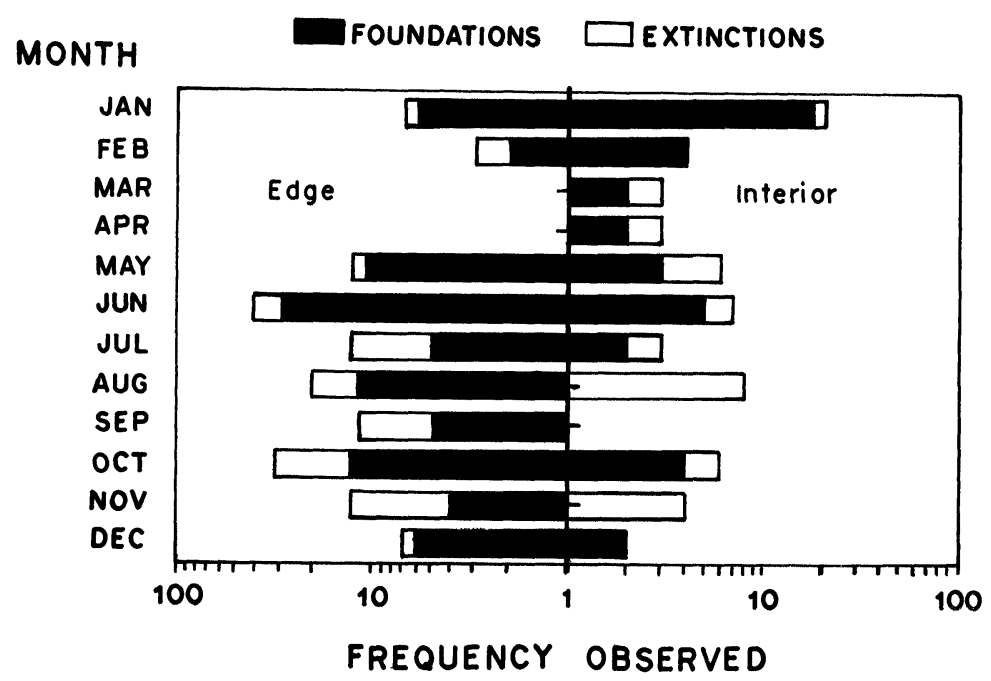

Fig. 1. Relation between monthly A. eximius colony foundations and extinctions in Amazonian forest edges and forest interiors. 
Table 1. The relation between colony extinctions and foundations with respect to site (forest interior or edge) and month.

\begin{tabular}{|c|c|c|c|c|}
\hline Source of Variation & MS & DF & F & $\mathbf{P}$ \\
\hline \multicolumn{5}{|c|}{ Overall foundations } \\
\hline Site & 18.06 & 1 & 6.506 & $<0.05$ \\
\hline Month & 90.743 & 11 & 8.249 & $<0.05$ \\
\hline Site $\times$ Month & 74.69 & 11 & 6.790 & $<0.05$ \\
\hline Error & 333.17 & 120 & & \\
\hline \multicolumn{5}{|c|}{ Overall extinctions } \\
\hline Site & 14.69 & 1 & 6.879 & $<0.05$ \\
\hline Month & 42.22 & 11 & 1.797 & ns \\
\hline Site $\times$ Month & 29.97 & 11 & 1.276 & ns \\
\hline Error & 256.33 & 120 & & \\
\hline
\end{tabular}

found between forest edge and interior. Colony foundations, however, varied significantly with respect to both setting and month (Fig. 1; Table 1). Monthly colony foundations were negatively correlated with monthly cumulative rainfall, $r=-0.448(P=0.028)$, but not colony extinctions, $\mathrm{r}=0.116(\mathrm{P}=0.588)$.

\section{DisCUSSION}

Our results confirm Vollrath's (1982) and Christenson's (1984) observations that colonies founded by solitary females have higher mortality rates than those founded by sociotomy. However, we were able to separate strategies used in colony foundation based upon habitat. Forest borders had statistically higher rates of colony foundation by solitary females than did continuous forest ( 9 times as great), but total rates of colonization were more than twice as high in the forest edge than in the forest interior, as expected for more unstable habitats (Kuno, 1981). However, colonies founded in the forest interior had significantly longer life spans than those founded on the forest edge, an effect previously not documented.

No significant monthly differences were found for colony extinctions. However, significant monthly differences were found for colony foundations. Both colony extinctions and foundations varied significantly between forest edge and interior. Contrary to 
our original hypothesis, colony foundations were negatively correlated with rainfall, unlike colony extinctions. Colony foundations occur at times of probable food shortage (dry months), while established colonies face a constant probability of extinction, irrespective of climatic conditions or setting. An alternative, but not mutually exclusive hypothesis, is that microclimatic fluctuations are more severe on the forest edge, inducing colony extinctions. This may explain significant differences in foundations and extinctions related with setting, which should also be driven by microclimate. In either case, whether food availability or microclimatic extremes push these dynamics is irrelevant. Forest edges, judged by dispersion criteria, are more unstable (Kuno, 1981).

The higher proportion of colony foundations by solitary females at forest edges suggests that this strategy may be in response to maintenance of genetic viability (Smith, 1986). This may also be in response to a higher overall web-spider abundance at forest edges (Vieira, 1990), which would limit available space for sociotomy, but not for solitary females. As sufficient data were lacking on the survivorship of colonies founded by solitary females in the forest interior, a comparison of colony survivorship could not be made. However, the greater frequency of sociotomy in the forest interior may indicate a more homogeneous environment, coupled with higher rates of inbreeding.

\section{SUMMARY}

Numbers of colonizations and extinctions of incipient colonies of the social spider Anelosimus eximius were greater at the edges of Amazonian forest than in continuous forest. The frequency of colony foundations by sociotomy, or groups, was higher in continuous forests than forest edges. Mean colony life spans for interior forest colonies were significantly longer, as well as colony life spans of colonies founded by sociotomy when compared with solitary foundations. Colony extinctions did not demonstrate monthly variations, although colony foundations showed significant differences, and were negatively correlated with monthly precipitation. We conclude that modes of colony foundation are habitat and seasonally dependent, related to the probability of survival. 
Key words: colonization, survivorship, sociotomy, dispersal, extinction, colony, spider, Anelosimus.

\section{ACKNOWLEDGEMENTS}

This study was supported by the Smithsonian Institution's and World Wildlife Fund's Biological Dynamics of Tropical Forest Fragments Project, and we are extremely grateful to its ex-director, Marina Wong, for her constant support and encouragement. Additional support was provided by the Conselho Nacional de Desenvolvimento Cientifico e Tecnologico $(\mathrm{CNPq})$ through grant 300171/88-9. We also wish to thank Rosemary Vieira, Angela Iwanama, and João de Deus Fragata for assistance in the field, Nozor Pinto for inking the figure, and Maria Thereza Fink for constant support. This is publication \#97 of the BDFFP Technical Series.

\section{Literature Cited}

AviLES, L.

1986. Sex ratio bias and possible group selection in the tropical social spider Anelosimus eximius. Am. Nat. 128: 1-12.

BRACH, V.

1975. The biology of the social spider Anelosimus eximius. Bull. So. Calif. Acad. Sci. 74: 37-41.

Christenson, T. E.

1984. Behavior of colonial and solitary spiders of the theridiid species Anelosimus eximius. Anim. Behav. 32: 752-764.

FOWLER, H. G. AND LEVI, H. W.

1979. A new quasi-social Anelosimus spider (Araneae, Theridiidae) from Paraguay. Psyche 86: 11-18.

Kahn, F. A. ANd CASTRo, A.

1985. The palm community of a rain forest of central Amazonia, Brazil. Biotropica 17: 210-216.

KunO, E.

1981. Dispersal and the persistence of populations in unstable habitats: a theoretical note. Oecologia 49: 123-126.

LEVI, H. W.

1956. The spider genera Neottiura and Anelosimus in America. Trans. Am. Microsc. Soc. 75: 407-420.

1963. The American spiders of the genera Aneolosimus (Araneae: Theridiidae). Trans. Am. Microsc. Soc. 82: 30-48.

1972. Taxonomic-nomenclatural notes on misplaced Theridiidae spiders (Araneae: Theridiidae) with observations on Anelosimus. Trans. Am. Microsc. Soc. 91: 533-538. 
Nentwig, W.

1985. Social spiders catch larger prey: a study of Anelosimus eximius (Araneae: Theridiidae). Behav. Ecol. Sociobiol. 17: 79-85.

Nentwig, W. And Christenson, T. E.

1986. Natural history of the non-solitary sheetweaving spider Anelosimus jucundus (Araneae: Theridiidae). Zool. J. Linn. Soc. 87: 27-35.

Pasquet, A. AND KRafFT, B.

1989. Colony distribution of the social spider, Anelosimus eximius (Araneae: Theridiidae), in French Guiana. Ins. Soc. 36: 173-182.

Pires, J. M. ANd Prance, G. T.

1985. The vegetation types of the Brazilian Amazon. Amazonia (Ed. by G. T. Prance \& T. E. Lovejoy TJ), pp. 109-145. Pergamon Press, New York.

Simon, E.

1891. Observations biologiques sur les arachnides. I. Araignées sociales. Ann. Soc. Ent. France 60: 5-14.

SMITH, D.

1986. Population genetics of Anelosimus eximius (Araneae: Theridiidae). J. Arachnol. 14: 201-227.

1989. Observations on the social spider Anelosimus domingo (Araneae: Theridiidae) in southwestern Peru. J. Arachnol. 17: 368-370.

Stejskal, $M$.

1976. Arañas sociales destructores de las plantas de café, citricos y mangoes en Venezuela. Turrialba 26: 343-350.

VIEIRA, R. S.

1990. Efeito da fragmentacão florestal sobre a comunidade de aranhas. B. S. Thesis, UNESP, Rio Claro, SP, Brazil.

VOLLRATH, F.

1982. Colony foundation in a social spider. Z. Tierpsychol. 60: 313-324.

1986a. Eusociality and extraordinary sex ratios in the spider Anelosimus eximius (Araneae: Theridiidae). Behav. Ecol. Sociobiol. 18: 283-287.

1986b. Environment, reproduction and the sex ratio of the social spider Anelosimus eximius. J. Arachnol. 14: 267-281. 

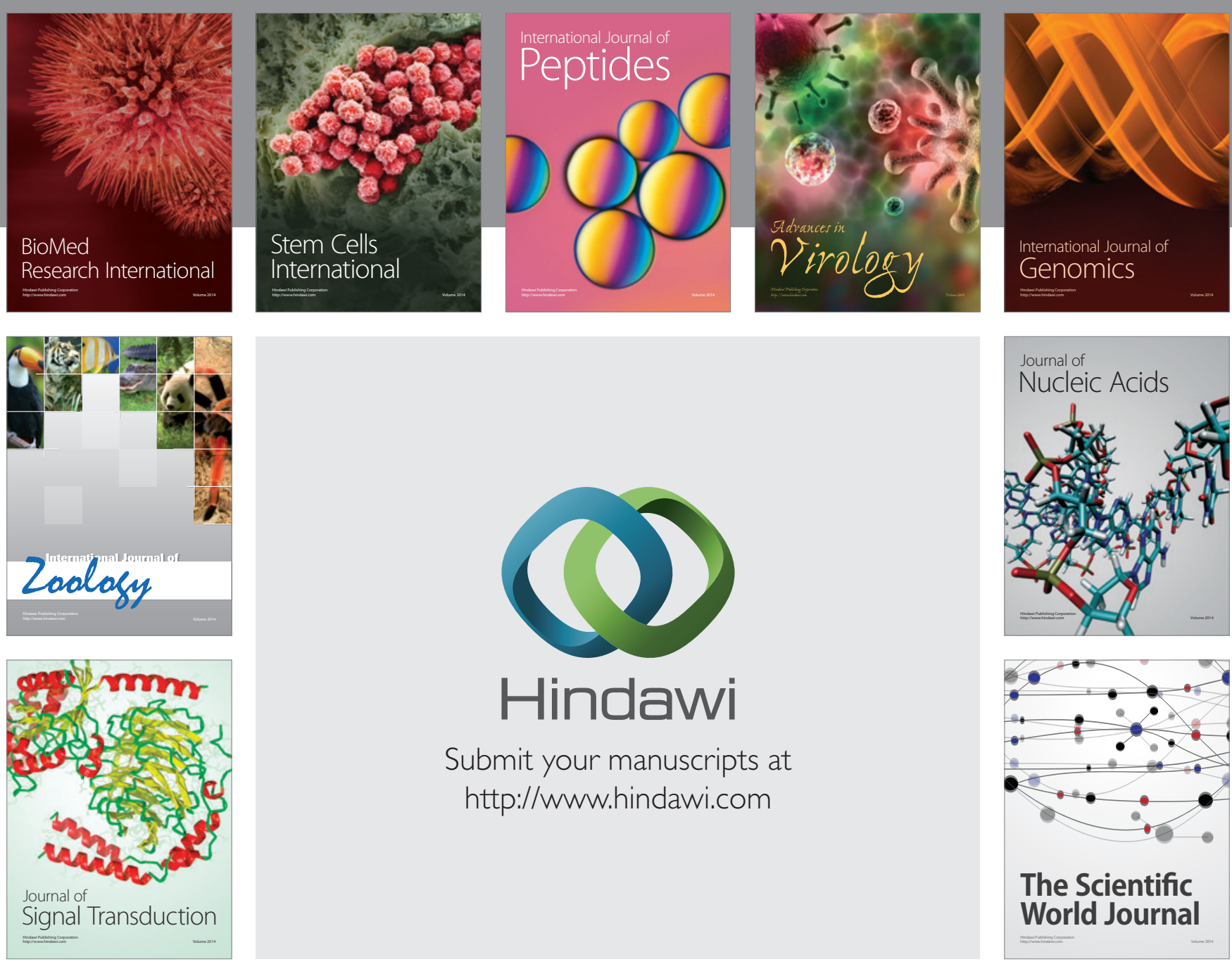

Submit your manuscripts at

http://www.hindawi.com
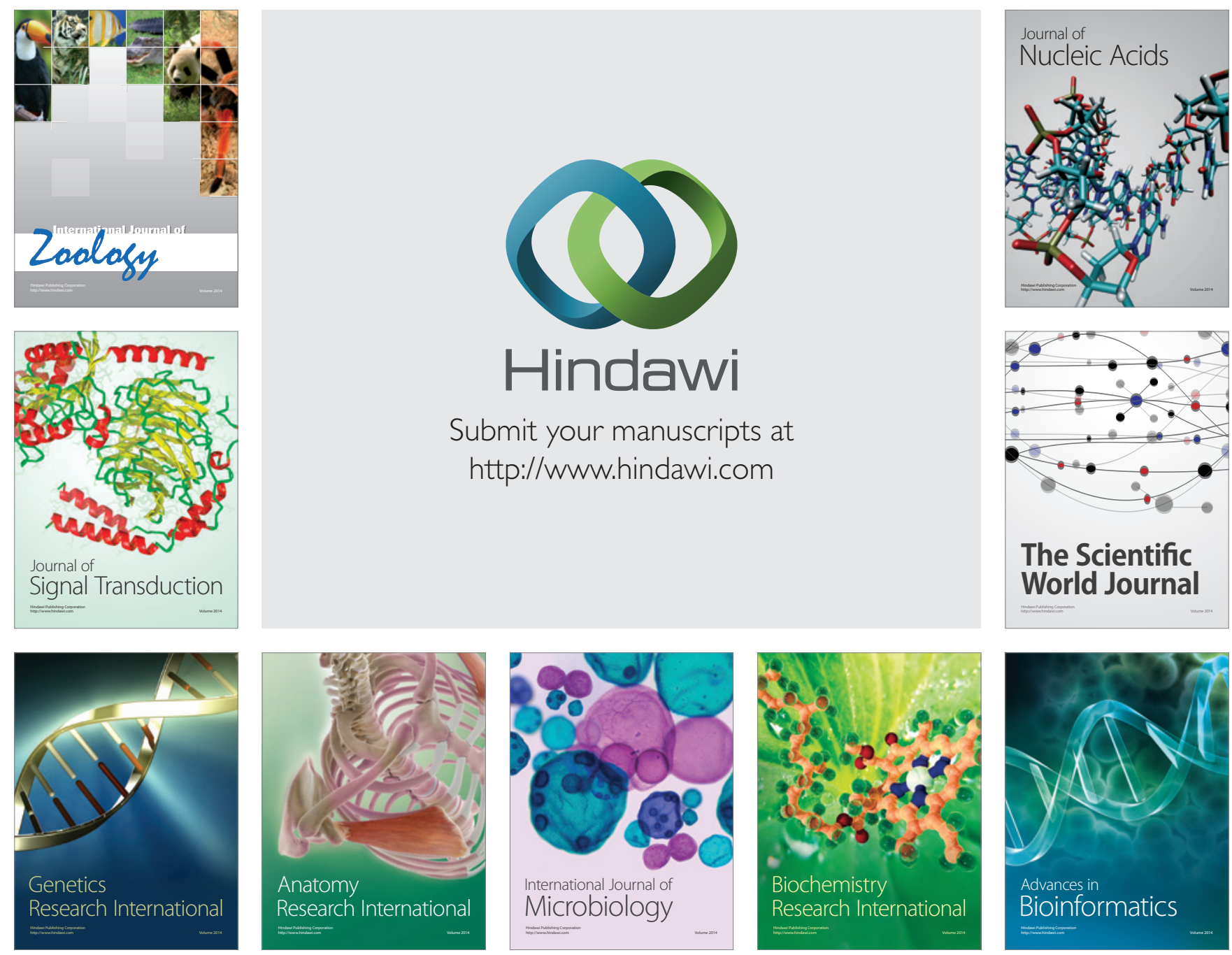

The Scientific World Journal
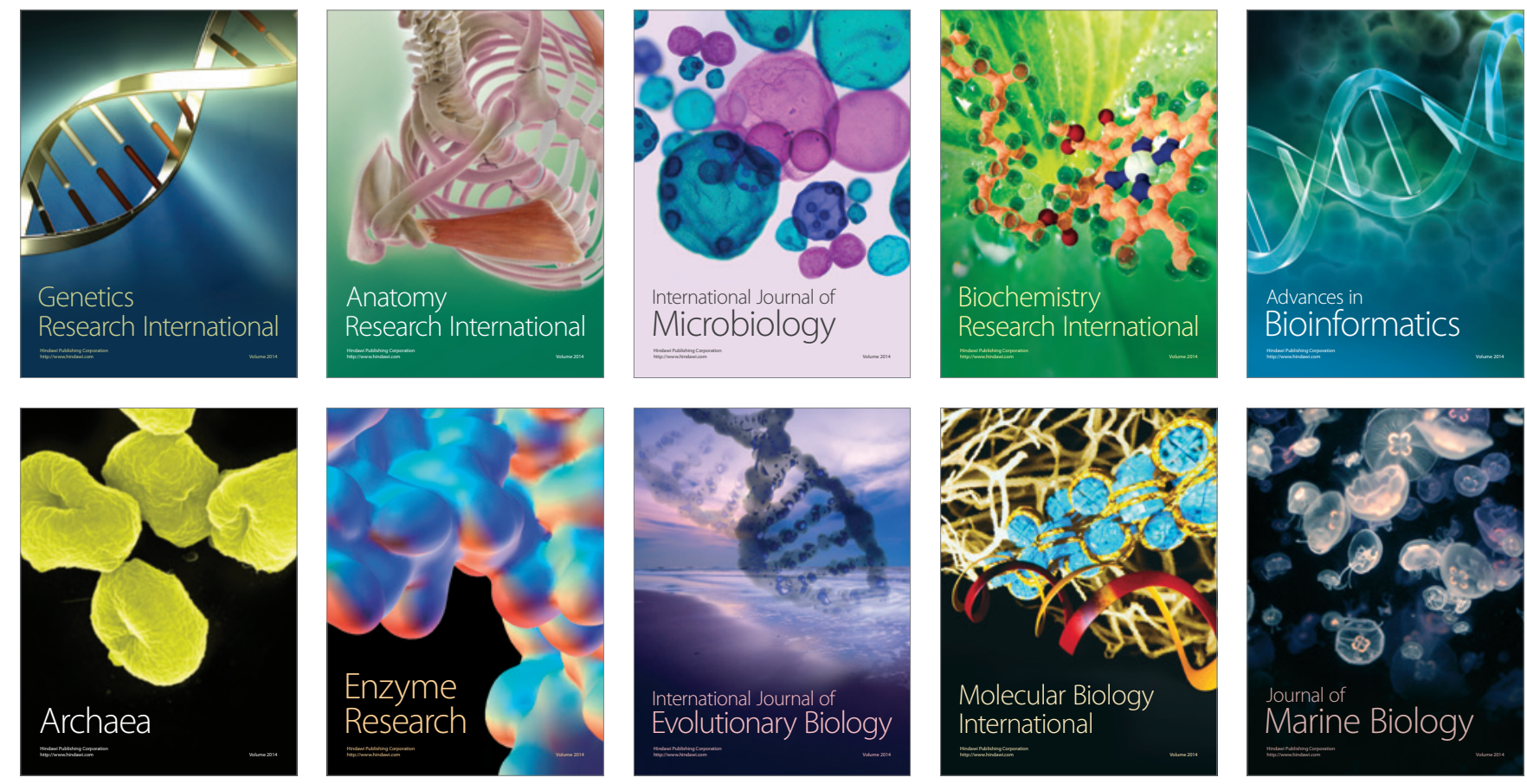